\title{
PERSPEKTIF UNDANG-UNDANG NOMOR 1 TAHUN 2011 TENTANG PERUMAHAN DAN KAWASAN PERMUKIMAN TERHADAP PERLINDUNGAN HAK KONSUMEN DALAM JUAL BELI PERUMAHAN
}

Oleh :

\author{
Ni Ketut Dewi Megawati ${ }^{1}$
}

\begin{abstract}
Abstrack
A mismatch between the administrative documents or the physical characteristics of a property offered in a contract and the actual conditions received by the client becomes an important problem in a property business. The property, which is the object of an agreement, should be in line with the legal aspects required by the legislation. The purpose of this study is to understand the legal condition of registering a property as the object of an agreement, by using consumer protection law in relation to property sales (i.e., Legislative Decree number 1 of 2011) as the perspectives. This study used normative legal framework based on Law and concept approaches as its research method. Several primary laws were collected and analyzed by a qualitative descriptive method. This study found that a property could be included as the object of an agreement if it fulfills the terms and conditions written in the Article 42 Clause 1 of Legislative Decree number 1 of 2011 on Real Estate and Residential Areas. Furthermore, a property can be an object of sales agreement if they meet several criteria written in the State Minister of Community Estate Decree's number 09/KPTS/M/1995, with the date of issuance on 23 June 1995, about the sale and purchase of a property. It can be argued that the Legislative Decree number 1 of 2011 on Real Estate and Residential Areas might not offer a comprehensive protection to the consumer rights, and subsequently inflict physical and mental harm to the consumers.
\end{abstract}

Keywords: Agreement, consumer rights, property, real estate

\begin{abstract}
Abstrak
Ketidaksesuaian dokumen administrasi dan fisik bangunan antara yang tercantum dalam penawaran dengan kenyataan yang diterima konsumen sering menjadi permasalahan pada bisnis perumahan. Rumah yang menjadi obyek perjanjian seharusnya telah memenuhi aspek legal yang dipersyaratkan oleh peraturan perundang-undangan. Tujuan penelitian ini untuk mengetahui syarat sahnya suatu perumahan untuk dapat dijadikan obyek perjanjian dan perspektif UU No. 1 Tahun 2011 terhadap perlindungan hak konsumen dalam jual beli perumahan. Metode dalam penelitian ini adalah penelitian hukum normatif dengan memakai pendekakan Undang-Undang dan pendekatan konsep dengan meneliti bahanbahan hukum primer yang dianalisis secara deskritif kualitatif. Dari hasil penelitian, syarat sahnya suatu perumahan untuk dapat dijadikan obyek dalam perjanjian pendahuluan apabila sudah memenuhi beberapa syarat sesuai dengan pasal 42 ayat (1) Undang-Undang No. 1 Tahun 2011 tentang Perumahan dan Kawasan Permukiman dan dapat dijadikan obyek dalam perjanjian jual beli apabila memenuhi syarat sesuai dengan yang diatur dalam Keputusan Menteri Negara Perumahan Rakyat Nomor 09/KPTS/M/1995 tanggal 23 Juni 1995

Mahasiswa Magister Ilmu Hukum Universitas Udayana, alamat Perum Dosen Kopertis Jalan Gutiswa VA No.7 Denpasar, email : dewimegawati@ymail.com
\end{abstract}


Tentang Pedoman Pengikatan Jual Beli Rumah. Dari perspektif Undang-Undang No. 1 Tahun 2011 tentang Perumahan dan Kawasan Permukiman belum secara nyata dapat melindungi hak-hak konsumen sehingga merugikan masyarakat selaku konsumen.

Kata Kunci : hak konsumen, perumahan, perjanjian.

\section{PENDAHULUAN}

\subsection{Latar Belakang}

Pertumbuhan ekonomi Indonesia yang cukup bagus dalam 1 dekade terakhir menyebabkan kebutuhan akan perumahan tidak lagi semata-mata hanya untuk pemenuhan kebutuhan akan tempat tinggal bagi masyarakat yang memang belum memiliki rumah. Namun kini motif kepemilikan rumah telah bergeser sebagai salah satu jenis investasi paling menjanjikan keuntungan yang cukup besar dibandingkan investasi lain.

Fungsi bank sebagai penyalur dana kepada masyarakat selain memberikan kredit modal kerja juga memberikan kredit di bidang investasi. ${ }^{2}$ Banyaknya perbankan yang menyediakan fasilitas kredit investasi di bidang perumahan atau Kredit Kepemilikan Rumah (KPR) menjadi salah satu faktor yang menyebabkan sebuah rumah lebih mudah untuk dijual.

Keterbatasan dana tunai yang dimiliki calon pembeli dapat di

Putu Eka Trisna Dewi, 2015, Implementasi Ketentuan Restrukturisasi Kredit Terhadap Debitur Wanprestasi pada Kredit Perbankan, Jurnal Magister Hukum Udayana Vol.4 No.2, Denpasar, Program Studi Magister Ilmu Hukum Pasca Sarjana Universitas Udayana, hlm. 242. fasilitasi melalui KPR dengan berbagai program uang muka kecil dan bunga rendah serta jangka waktu cicilan yang panjang.

Bahkan ada Bank BUMN yang khusus bergerak di bidang pembiayaan perumahan dengan program unggulan pembiayaan KPR untuk masyarakat menengah ke bawah. Tanpa adanya fasilitas pembiayaan dari perbankan, sebuah rumah akan menjadi lebih sulit untuk dijual karena hanya sedikit masyarakat yang memiliki kemampuan untuk membeli sebuah rumah yang tentunya harganya sangat tinggi secara tunai.

Tingginya permintaan terhadap perumahan berbanding terbalik dengan keterbatasan lahan yang dapat di alih fungsikan. Permintaan yang tinggi apabila tidak diimbangi dengan penawaran barang yang sepadan akan menyebabkan kenaikan terhadap barang tersebut. ${ }^{3}$ Keterbatasan jumlah perumahan tersebut menyebabkan harga perumahan cenderung meningkat.

Ketimpangan antara permintaan dan ketersediaan rumah menyebabkan pengembang lebih berorientasi kepada

Sadono Sukirno, 2012, Mikro Ekonomi : Teori Pengantar, Edisi 3, Jakarta, Rajawali Pers, hlm.85. 
kecepatan dalam menyelesaikan perumahan tersebut dibandingkan sisi kualitas yang sebelumnya telah ditawarkan kepada konsumen. Semakin cepat suatu proyek selesai maka keuntungan yang di dapatkan pengembang akan semakin besar dan konsumen pun akan merasa senang karena rumah yang telah mereka beli dapat ditempati dengan cepat.

Jumlah permintaan yang lebih banyak dari penawaran menyebabkan konsumen berada pada posisi tawar yang rendah, karena bila seorang konsumen terlalu banyak menuntut kepada pengembang, pengembang dengan posisi tawar yang tinggi akan menekan konsumen dengan cara mengembalikan tanda jadi atau uang muka dan akan menjualnya kembali kepada konsumen lain. Pada akhirnya, konsumen yang sangat memerlukan rumah hanya bisa menerima saja apabila terdapat ketidaksesuaian antara kuantitas, kualitas bahan dan hal lainnya dari yang semula di janjikan oleh pengembang.

Konsumen yang berada pada posisi tawar rendah tersebut memilih untuk tidak melakukan upaya hukum apapun terhadap pengembang dikarenakan kebutuhan mereka untuk segera menempati rumah tersebut lebih mendesak dibandingkan hal lainnya.

Permasalahan hukum dalam jual beli perumahan diantaranya ketidaksesuaian antara apa yang tertera di dalam brosur dengan yang diterima konsumen saat menempati rumah tersebut. Seperti kualitas spesifikasi rumah yang rendah, perbedaan luas tanah, keterlambatan penyerahan bangunan, masalah fasilitas sosial dan umum, dan sebagainya.

Yusuf Shofie berpendapat bahwa pemasaran perumahan dari pengembang sangat tendensius ${ }^{4}$. Para calon pembeli dituntut teliti sebelum membeli, mereka harus mengetahui dengan benar mengenai siapa pengembang, kualitas bangunan dan sebagainya. Konsumen hanya diyakinkan melalui brosur, maket, rumah contoh dan penawaran staf pemasaran, padahal produknya masih berupa konsep.

Pengembang menuntut konsumen untuk memenuhi kewajiban dalam kepemilikan rumah tapi di sisi lain pengembang sering kali mengabaikan hak-hak yang seharusnya didapatkan oleh konsumen. UU No.8 Tahun 1999 tentang Perlindungan Konsumen secara khusus mengatur permasalahan konsumen dan memberi wadah bagi aspirasi dan advokasi yang akan dilakukan konsumen jika terjadi tindakan tidak bertanggung jawab yang dilakukan oleh pelaku usaha. Meskipun belum sempurna, akan tetapi adanya Undang-Undang ini merupakan suatu langkah maju dalam rangka menciptakan kegiatan usaha yang sehat di Indonesia dalam upaya memberikan perlindungan kepada konsumen.

\footnotetext{
$4 \quad$ Yusuf Shofie, 2003, Perlindungan Konsumen dan Instrumen Hukumnya, Bandung, Citra Aditya Bakti, hlm.86.
} 
Dalam Pasal 1338 (KUHPerdata) telah diatur bahwa semua persetujuan yang dibuat secara sah berlaku sebagai undang-undang bagi mereka yang membuatnya. Berdasarkan ketentuan di atas maka dapat diuraikan bahwa :

a. Segala hal yang diperjanjikan oleh konsumen dengan pengembang berlaku sebagai undang-undang bagi konsumen dengan pengembang.

b. Segala hal yang sudah diperjanjikan tidak dapat ditarik kembali kecuali atas persetujuan dari konsumen dan pengembang atau karena alasan-alasan yang ditentukan oleh undang-undang.

c. Segala hal yang sudah diperjanjikan harus dilaksanakan dengan itikad baik.

Terkait dengan aturan tersebut maka merebaknya kasus perumahan pada dasarnya diawali dengan tindakan-tindakan melanggar perjanjian yang dilakukan oleh pihak pengembang. Dalam perkembangan, bisnis perumahan ini menjadi celah bagi pihak pengembang untuk melakukan tindakan-tindakan yang merugikan pihak konsumen karena tidak dipenuhinya yang menjadi kewajiban dari pihak pengembang setelah batas waktu yang ditentukan ${ }^{5}$.

Tidak adanya akibat hukum terhadap proses perjanjian pendahuluan membuat para pihak berada pada ketidakpastian. Penyimpangan yang

Salim HS,dkk, 2008, Perancangan Kontrak dan Memorandum of Understanding (MoU), Jakarta, Sinar Grafika, hlm.54. dilakukan pihak pengembang dan tidak ditindak lanjuti oleh pemerintah dapat menimbulkan kerugian bagi konsumen perumahan, bahkan dalam kasus yang sering terjadi, perumahan yang dijual oleh pengembang bahkan bertentangan dengan Pasal 42 UU No.1 Tahun 2011 tentang Perumahan dan Kawasan Permukiman.

\subsection{Perumusan Masalahan}

Dari latar belakang masalah tersebut, maka dirumuskan permasalahan:

1. Bagaimanakah syarat sahnya suatu perumahan untuk dapat dijadikan obyek perjanjian?

2. Bagaimanakah perspektif UU No.1 Tahun 2011 tentang Perumahan dan Kawasan Permukiman terhadap perlindungan hak-hak konsumen dalam jual beli perumahan?

\subsection{Tujuan Penelitian}

Penelitian ini bertujuan untuk mengetahui syarat sahnya suatu perumahan untuk dapat dijadikan obyek perjanjian dan perspektif UU No.1 Tahun 2011 tentang Perumahan dan Kawasan Permukiman terhadap perlindungan hak-hak konsumen dalam bisnis perumahan.

\section{METODE PENELITIAN}

Metode yang dipergunakan dalam penelitian ini adalah penelitian hukum normatif dengan menggunakan pendekakan undang-undang dan pendekatan konsep dengan meneliti bahan hukum primer dan bahan 
hukum sekunder yang dianalisis secara deskritif kualitatif.

III. HASIL DAN PEMBAHASAN 3.1. Syarat sahnya suatu perumahan untuk dapat dijadikan obyek perjanjian Permasalahan

dalam bisnis perumahan diantaranya ketidaksesuaian antara apa yang tercantum dalam penawaran dengan barang atau rumah yang diterima konsumen. Larangan terhadap hal tersebut telah diatur dalam pasal 134 UU No.1 Tahun 2011.

Iklan atau promosi merupakan suatu alat dari pelaku usaha dalam upaya menarik minat konsumen dan berharap konsumen akan membeli atau mengkonsumsi produk tersebut. Dalam usaha menarik konsumen, iklan terkadang berlebihan atau tidak sesuai dengan barang yang dijual. Iklan yang menyesatkan banyak dijumpai di berbagai media massa maupun sarana promosi lainnya.

Melalui iklan, pengembang ingin secepatnya mendapatkan konsumen dengantujuanuntukmemastikanbahwa unit rumah yang mereka bangun dapat terjual sebelum perumahan tersebut selesai. Pengembang melakukan hal ini dikarenakan modal yang mereka gunakan untuk membangun bersumber dari pembiayaan lembaga keuangan atau bank sehingga semakin lama suatu unit perumahan terjual maka beban bunga terhadap pinjaman yang telah diambil akan semakin besar. Contohnya, dalam brosur perumahan pada umumnya disebutkan tentang spesifikasi bangunan, jenis kepemilikan tanah dan fasilitas-fasilitas pendukung yang ditawarkan tetapi beberapa bulan setelah akad kredit atau penandatanganan perjanjian jual beli tersebut ternyata obyek perjanjian dalam hal ini perumahan belum siap untuk ditempati dan fasilitas umum serta status lahannya tidak seperti yang dijanjikan dalam brosur. Dalam beberapa kasus perumahan setelah perumahan selesai dibangun ternyata status lahan adalah SHGB sedangkan di brosur disebutkan SHM.

Dalam pasal 42 ayat (1) UndangUndang No.1 Tahun 2011 dijelaskan bahwa perjanjian pendahuluan dalam bisnis perumahan baru dapat dilakukan setelah memenuhi beberapa persyaratan yaitu :

a. Status pemilikan tanah.

Sertifikat atas tanah yang diperjualbelikan harus sudah terbit dan atas nama pengembang sehingga terjamin kepastian hukum dalam proses transaksi.

b. Hal yang diperjanjikan.

Hal yang diperjanjikan sebatas perjanjian pendahuluan yang bersifat mengikat sementara para pihak dan akan menjadi dasar dalam melakukan perjanjian jual beli

c. Kepemilikan izin mendirikan bangunan (IMB) induk.

IMB induk wajib telah dimiliki oleh pengembang sebelum pengembang memasarkan rumahnya kepada konsumen karena IMB merupakan bukti 
bahwa perumahan yang akan dibangun sudah memenuhi peraturan yang dipersyaratkan.

d. Ketersediaan prasarana, sarana, dan fasilitas umum.

Ketersediaan sarana perumahan tersebut merupakan kewajiban penyelenggara pembangunan perumahan dan pemukiman. ${ }^{6}$ Fasilitas umum wajib disediakan oleh pengembang dan tertuang dalam dokumen perjanjian pendahuluan serta masuk dalam gambar pada IMB induk.

e. Telah selesai dibangun minimal $20 \%$.

Perumahan yang telah dibangun minimal 20\% merupakan salah satu syarat dalam pengajuan IMB sehingga secara hukum pengembang tidak berhak menjual rumah yang belum memiliki IMB.

Perjanjian Pendahuluan (pactum decontrahendo)diaturdalampasal 1320 (1) jo 1338 KUHPerdata. Perjanjian Pendahuluan adalah perjanjian yang digunakan sebagai pendahuluan untuk mengadakan perjanjian lain yang lebih pasti. Yang disepakati dalam Perjanjian Pendahuluan hanya pokok perjanjian dan belum mengatur tentang rincian kewajiban. Perjanjian Pendahuluan akan ditindak lanjuti ke dalam perjanjian tertentu dan digunakan sebagai pendahuluan untuk perjanjian kompleks.

Pada dasarnya Perjanjian Pendahuluan dalam jual beli benda,

6 Ajiraksa, 2002, Perencanaan dan Pengembang Perumahan, Jakarta, PT. Citra Adithya Bakti, hlm 182. para pihak sepakat bahwa hak milik atas obyek jual beli tersebut pada suatu waktu yang akan datang akan berpindah kepada pihak pembeli. Hal ini berbeda dengan perjanjian jual beli dimana hak milik atas benda seketika berpindah kepada pihak pembeli. ${ }^{7}$

Perjanjian Pendahuluan Jual Beli (PPJB) harus mengikuti pedoman yang ditetapkan dalam Keputusan Menteri Negara Perumahan Rakyat Nomor 09/KPTS/M/1995 tanggal 23 Juni 1995 Tentang Pedoman Pengikatan Jual Beli Rumah yang menjadi dasar hukum dalam melakukan transaksi jual beli antara pengembang dengan konsumen.

Dalam Keputusan Menteri tersebut, suatu perumahan dapat dijadikan sebagai obyek perjanjian apabila telah memenuhi persyaratan :

a. Pengembang telah menyelesaikan pendirian bangunan perumahan dan telah siap untuk dihuni sesuai dengan waktu yang telah diperjanjikan menurut gambar arsitektur, denah, dan spesifikasi teknis bangunan.

b. Memiliki surat ijin persetujuan prinsip rencana proyek dari Pemerintah Daerah setempat dan surat ijin lokasi dari Kantor Pertanahan Kabupaten/ Kotamadya.

c. Surat keterangan dari Kantor Pertanahan Kabupaten/

Abdul Kadir Muhamad, 1980, Hukum Perjanjian, Bandung, Alumni, hlm.243. 
Kotamadya yang menerangkan bahwa pengembang telah memperoleh tanah untuk pembangunan perumahan dan permukiman.

d. Memiliki Surat Ijin Mendirikan Bangunan.

e. Pengembang telah mengurus pendaftaran memperoleh hak atas tanah dan bangunan rumah.

Apabila persyaratan tersebut tidak dapat dipenuhi oleh pengembang, maka pihak pengembang dilarang untuk menjual rumahnya tersebut terutama jika belum menyelesaikan status hak atas tanahnya. ${ }^{8}$

Berdasarkan uraian tersebut dapat diartikan bahwa selama obyek yang diperjualbelikan belum memenuhi syarat administrasi seperti yang diatur dalam pasal 42 ayat (1) UU No.1 Tahun 2011 maka perumahan tersebut tidak bisa menjadi obyek perjanjian dalam artian tidak bisa diperjualbelikan. Bahkan perumahan yang masih dalam tahap pembangunan pun hanya boleh menjadi obyek dalam Perjanjian Pendahuluan dan tidak bisa menjadi obyek dalam Perjanjian Jual Beli.

Kallo Ermin, 2009, Perspektif Hukum Dalam Dunia Property, Jakarta, Minerva Athena Pressindo, hlm 48-50
3.2. Perspektif Undang-Undang No.1 Tahun 2011 Tentang Perumahan dan Kawasan Permukiman Terhadap Perlindungan Hak-Hak Konsumen Dalam Jual Beli Perumahan

Permasalahan dalam binis perumahan pada umumnya menempatkan konsumen dalam posisi yang lemah. Sulistyowati melihat 6 poin penting yang merugikan konsumen, dalam upaya mendapatkan perumahan, yaitu : 9

a. semakin tingginya harga rumah;

b. para pengembang swasta enggan membangun rumah jenis sederhana, karena dirasakan keuntungan yang akan didapat sangat kecil;

c. pengembang sering tidak memperhatikan kepentingan para konsumen, dengan mengingkari janji akan penyediaan sarana dan prasarana umum;

d. keadaan perumahan senyatanya tidak sesuai dengan yang dijanjikan;

e. kualitas rumah yang buruk; dan

f. administrasi cicilan BTN yang tidak rapi.

Kurangnya pengetahuan konsumen akan hak-haknya sebagai seorang warganegara Republik Indonesia sering disalahgunakan

\footnotetext{
Sulistyowati, 1992, Akses Kepada Perlindungan Konsumen Sebagai Salah Satu Aspek Kesejahteraan Sosial, Jakarta, Universitas Indonesia, hlm.20.
} 
oleh pengembang perumahan dalam menyediakan perumahan serta lingkungan yang memenuhi syarat. Kerugian ini banyak dialami oleh konsumen yang membeli rumah di perumahan komersial. Seiring meningkatnya jumlah penduduk yang relatif banyak, maka dewasa ini pertumbuhan perumahan pun relatif semakin meningkat. ${ }^{10}$

Mencermati hal tersebut diatas, perlindungan hukum terhadap konsumen perumahan di Indonesia masih lemah sehingga perlu keterlibatan seluruh pemegang kebijakan atau institusi terkait baik itu yang ada di pusat maupun daerah untuk secara bersama memperjuangkan nasib konsumen perumahan.

Pemerintah hingga saat ini belum memiliki sistem dan peraturan yang saling bersinergi dan jelas untuk menindaklanjuti permasalahan di bidang perumahan. Berbagai regulasi yang mengatur tentang perumahan berada di lintas kementerian dan daerah. Salah satu contoh riil yang kerap terjadi adalah tentang peruntukan sebidang tanah. Badan Pertanahan Nasional (BPN) merupakan lembaga yang diberi amanat oleh Undang-Undang Pokok Agraria Nomor 5 Tahun 1960 untuk menerbitkan sertifikat dan menentukan peruntukan sebidang lahan tersebutatas rekomendasi pemerintah daerah. Di sisi lain peruntukan pemanfaatan lahan

10 Edi As' Adi, 2011, Hukum Proyek Konstruksi Bangunan (Dalam Perspektif Pelayanan Publik yang Baik di Indonesia), Yogyakarta, Graha Ilmu, hlm. 2. melalui Ijin Mendirikan Bangunan (IMB) dikeluarkan oleh Kabupatan/ Kota mengacu kepada Perda tentang Rencana Tata Ruang dan Wilayah (Perda RTRW) yang dimiliki setiap Kabupaten/Kota. Terkadang terjadi sertifikat yang terbit peruntukannya adalah perumahan tetapi pada saat pengajuan IMB, Pemerintah Kabupaten/Kota menilai bahwa tanah tersebut peruntukannya adalah Ruang Terbuka Hijau Kota sesuai dengan Perda RTRW setempat.

Perbedaan ini terjadi akibat regulasi yang tidak tegas mengatur fungsi dan wewenang masingmasing jenjang pemerintahan. Kata rekomendasi dapat menjadi celah bagi pihak-pihak yang memiliki itikad tidak baik karena kata rekomendasi tidak memiliki kekuatan hukum memaksa dan mengikat secara kuat, hal ini akan menimbulkan ketidakpastian hukum yang pada akhirnya akan merugikan konsumen.

Di sisi lain, konsumen merupakan jantung dari tumbuhnya sektor perumahan. Pemerintah harusnya membangun sistem yang saling bersinergi sehingga masyarakat akan terlindungi dari kemungkinan kerugian yang mungkin akan dialami karena adanya celah dalam berbagai peraturan yang kurang bersinergi.

Permasalahan lain yang juga sering muncul dalam bisnis perumahan antara lain keterlambatan serah terima rumah, masalah sertifikasi, mutu bangunan, informasi marketing yang menyesatkan, fasilitas sosial dan 
fasilitas umum yang tidak dibangun atau tidak memadai serta pengenaan biaya tambahan.

Dalam UU No. 8 Tahun 1999 dan UU No. 1 Tahun 2011 telah mengatur tentang hak dan kewajiban konsumen dan pengembang perumahan. Bahkan untuk mengurangi pelanggaran hak konsumen dalam UU No. 1 Tahun 2011 telah melibatkan Pemerintah Provinsi dan Pemerintah Kabupaten/Kota untuk mengurus dan mengawasi pengadaan perumahan dan kawasan permukiman di masing-masing wilayahnya seperti yang tertuang dalam pasal 12 sampai pasal 18 yang mengatur tugas dan kewenangan Pemerintah, Pemerintah Provinsi, dan Pemerintah Kabupaten/ Kota.

Pengaturan tentang hak konsumen dalam UU No. 1 Tahun 2011 tertuang dalam pasal 129 dan 130. Dalam konteks perlindungan konsumen, hak bagi konsumen adalah kewajiban yang harus dipenuhi oleh pelaku usaha. Tidak bisa dihindari bahwa pelanggaran atas kewajiban dari pelaku usaha merupakan pelanggaran atas hak konsumen. Untuk menghindari terjadinya pelanggaran, tidak hanya ditentukan oleh pemenuhan kewajiban dari pelaku usaha tetapi pihak konsumen perumahan juga harus teliti dalam memilih perumahan berkualitas dengan pengembang yang bertanggungjawab.

Rekam jejak pengembang menjadi variabel yang sangat penting dalam transaksi perumahan dalam menjamin terpenuhinya semua hak konsumen. Pengembang yang sudah memiliki rekam jejak baik dan sudah memiliki pengalaman yang panjang di bisnis perumahan tidak akan mengorbankan reputasi yang sudah mereka bangun sangat lama karena dalam bisnis apapun terutama bisnis perumahan yang melibatkan sumber daya modal yang sangat besar kepercayaan adalah hal yang sangat penting. Konsumen sebelum memutuskan membeli rumah wajib untuk menelusuri lebih dalam mengenai informasi terkait perumahan yang akan dipilih dengan lebih obyektif dalam menyikapi berbagai iklan dan promosi yang terkadang menyesatkan dari pengembang.

\section{PENUTUP}

\subsection{Simpulan}

Berdasarkan uraian pembahasan sebelumnya dapat di simpulkan sebagai berikut :

1. Syarat sahnya suatu perumahan untuk dapat dijadikan obyek dalam Perjanjian Pendahuluan berdasarkan pasal 42 ayat (1) UU No. 1 Tahun 2011 tentang Perumahan dan Kawasan Permukiman adalah status kepemilikan tanah sudah jelas dibuktikan dengan sertifikat, hal yang diperjanjikan sebatas Perjanjian Pendahuluan, kepemilikan Ijin Mendirikan Bangunan (IMB) induk sudah diterbitkanolehpihakberwenang, 
ketersediaan fasilitas umum, dan bangunan tersebut telah selesai dibangun minimal 20 persen.

Sedangkan untuk dapat menjadi obyek perjanjian jual beli, sebuah perumahan harus sesuai dengan persyaratan seperti yang diatur dalam Kepmen Perumahan RakyatNomor09/KPTS/M/1995 tanggal 23 Juni 1995.

2. UU No. 1 Tahun 2011 tentang Perumahan dan Kawasan Permukiman belum secara nyata dapat melindungi hak-hak konsumen dalam bisnis perumahan sehingga mengakibatkan praktekpraktek bisnis perumahan yang berkembang merugikan masyarakat selaku konsumen.

\subsection{Saran}

1. Pemerintah Pusat, Provinsi, Kabupaten/Kota sebagai pemegang kebijakan perlu bersinergi dalam menata kembali berbagai peraturan di bisnis perumahan agar dapat menjamin terlindunginya hakhak konsumen dari segala bentuk praktek bisnis yang tidak sehat.

2. Pemerintah perlu memberdayakan peguyuban atau asosiasi pengembang perumahan sebagai tempat melakukan monitoring terhadap pelaku usaha atau pengembang yang melakukan praktek bisnis tidak sesuai dengan aturan sehingga masyarakat akan mudah mengakses rekam jejak pengembang di asosiasi tersebut.

3. Masyarakat perlu lebih waspada dan teliti dalam melakukan transaksi perumahan dengan mencermati berbagai dokumen administrasi perumahan yang diperjualbelikansepertisertifikat, status tanah dan IMB.

\section{DAFTAR PUSTAKA}

Abdul Kadir Muhammad, 1980, Hukum Perjanjian, Bandung, Alumni.

Ajiraksa, 2002, Perencanaan dan Pengembang Perumahan, Jakarta, PT. Citra Adithya Bakti

Edi As' Adi, 2011, Hukum Proyek Konstruksi Bangunan (Dalam PerspektifPelayanan Publikyang Baik di Indonesia),Yogyakarta, Graha Ilmu

Kallo Ermin, 2009, Perspektif Hukum Dalam Dunia Property, Jakarta, Minerva Athena Pressindo

Putu Eka Trisna Dewi, 2015, Implementasi Ketentuan

Restrukturisasi Kredit Terhadap

Debitur Wanprestasi pada Kredit Perbankan, Jurnal Magister Hukum Udayana Vol.4 No.2, Denpasar, Program studi Magister IlIlmu Hukum Pasca Sarjana Universitas Udayana

Sadono Sukirno, 2012, Mikro Ekonomi: Teori Pengantar, Edisi 3, Jakarta, Rajawali Pers. 
Salim HS,dkk, 2008, Perancangan

Kontrak dan Memorandum

of Understanding (MoU),

Jakarta,Sinar Grafika

Sulistyowati, 1992, Akses Kepada Perlindungan Konsumen Sebagai

Salah Satu Aspek Kesejahteraan

Sosial, Jakarta, Universitas Indonesia.

Yusuf Shofie; Perlindungan Konsumen dan Instrumen Hukumnya, Bandung, Citra Aditya Bakti

\section{PERATURAN PERUNDANG}

\section{UNDANGAN}

Kitab Undang Undang Hukum Perdata.

Undang-Undang No. 1 Tahun 2011

Tentang Perumahan dan

Kawasan Permukiman

Undang-Undang No. 8 Tahun 1999 Tentang Perlindungan

Konsumen. 